\title{
ACCOMMODATING STAKEHOLDERS' VOICES IN THE CURRICULUM DEVELOPMENT IN AN INDONESIAN HIGHER EDUCATION INSTITUTION
}

Siti Nur Hidayah*

Education Futures Unit, University of South Australia, Australia

E-mail: siti.bidayab@mymail.unisa.edu.au

Wisjnu Martani

Faculty of Psychology, Universitas Gadjah Mada, Yogyakarta, Indonesia

Email:wisjnu_m@ugm.ac.id

\section{Wahyu Supartono}

Faculty of Agricultural Technology, Universitas Gadjah Mada, Yogyakarta, Indonesia Email:wstono@yahoo.com

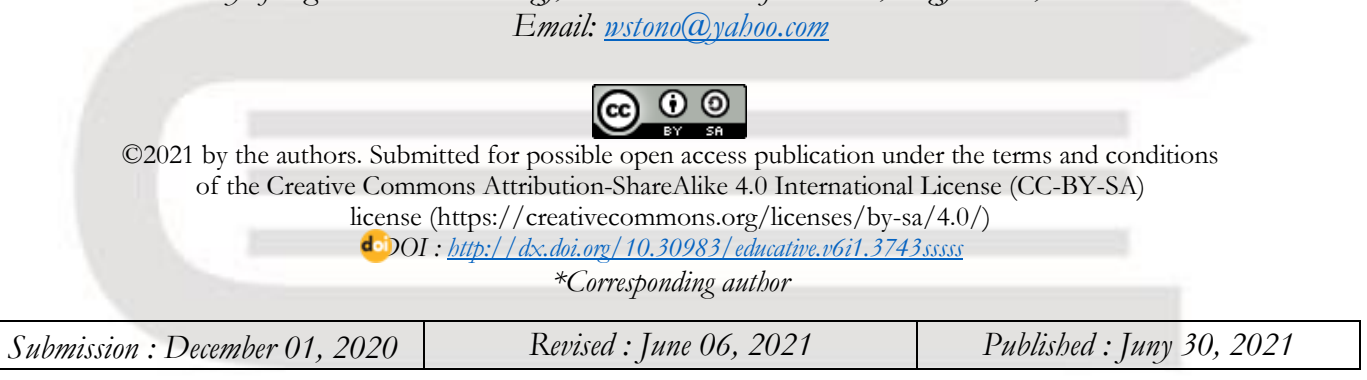

This article aims to investigate the accommodation of stakeholders' voices and it's challenges in the practices of curriculum development. Using a qualitative approach, the primary data was gathered through in-depth interviews with the head and secretary, and the administrative staff of four Study Programs in The School of Post Graduate Program of one of the leading universities in Yogyakarta, Indonesia. Whereas, secondary data was taken from the documents of curriculum reviews and accreditation documents. The research found that amidst the complexity of involving stake holder's views within curriculum design, all the four programs have gathered the stake holders' voices via tracer study, informal discussion during academic meetings and evaluation from the students. The accommodation of stake holders' voices can be traced in the form of the addition of elective courses, merging of some courses, addition or omission of certain courses in the current curriculum design. However, the practice of curriculum development was challenged by various aspects such as the commitment of Study Programs to maintain their 'scientific core' vis a vis addressing market demand given their commitment to improve theories and knowledge, and the limitation of human resource availability.

Keywords: curriculum development, higher education institution, market demand, stake holder, tracer study.

\section{Abstrak}

Artikel ini Betjeman untuk meneliti akomodasi terbadap masukan stakeholder serta tantangannya dalam praktik. pengembangan kurikulum. Menggunakan pendekatan kualitatif, data primer dikumpulkan melalui wawancara dengan ketua dan sekretaris, dan staf administrasi pada empat program studi di Program Pascasarjana di salah satu universitas terkemuka di Yogyakarta, Indonesia. Sementara itu, data sekunder diambil dari dokumen review kurikulum dan akreditasi. Penelitian ini menemukan bahwa di tengah kompleksitas pelibatan stake holder dalam desain kurikulum, keempat Program Studi mengumpulkan masukan stakeholder melalui tracer study, diskusi informal dalam pertemuanpertemuan akademik dan evaluasi dari mahasiswa. Akomodasi yang dilakukan Program Study dapat dilacak dalam bentuk penambahan mata kuliah tambahan, penggabungan beberapa mata kuliah, penambahan atau pengurangan mata kuliah tertentu dalam desain kurikulum yang baru. Akan tetapi, pelaksanaan pengembangan kurikulum tersebut menghadapi tantangan berupa komitmen Program Studi untuk. mempertahankan 'inti keilmuan' dihadapkan dengan bagaimana mengakomodir tuntutan pasar mengingat bahwa Program Studi memiliki komitmen untuk pengembangan teori dan pengetabuan, dan keterbatasan sumber daya manusia di Program Studi.

Kata Kunci: pengembangan kurikulum, Pendidikan Tinggi, pemangku kepentingan, studi pelacakan, tuntutan pasar. 


\section{Introduction}

Higher degree institutions around the world are facing global challenges to accommodate stakeholders' views on their graduate's employability. ${ }^{1}$ These perceptions have challenged traditional notions of higher education and often question the value of having a university degree and understanding the subjects and courses ${ }^{2}{ }^{3}$. Higher degree institutions are believed to produce competence, qualified human resource, and contribute to prepare human capital particularly in supporting economic development. The development of the number of students who graduated from universities have substantially contributed to economic growth ${ }^{4}$. The investment in higher degree institutes made by South Korea have proven to significantly grown their country's economy rather than the investment in primary education as initiated by Brazil ${ }^{5}$. This is particularly true because the graduate education is the most essential tools to develop research, innovation, and theories ${ }^{6}$.

On the other hand, the investment in higher education institutions in Indonesia was scrutinized of leaving some problem of unemployment. Even though, the graduates from universities were contributing quite low

1 A. Diver, Employability via Higher Education: Sustainability as Scholarship Edited by Alice Diver, 1st ed. 20. (Cham: Springer International Publishing: Imprint: Springer., 2019), https://doi.org/10.1007/978-3-03026342-3.

2 David C Bueno, “Ascertaining the Curriculum Relevance of the Graduate School through Tracer Study in a Philippine Private Higher Education Institution," JPAIR Multidisciplinary Research Journal 28, no. 1 (2017): 1.

${ }^{3}$ Margaret Sims, Bullshit Towers: Neoliberalism and Managerialism in Universities in Australia (Peter Lang, 2020).

${ }^{4}$ Domingo G Echevarria, "The Contribution of Higher Education to Economic* Development in a Globalized Environment" (Florida International University, 2009).

5 T. S. Prihatiningsih, “Trans-, Multi- Dan InterDisciplinary Higher Education'," (Universitas Gadjah Mada, 2013).

${ }^{6}$ Bueno, "Ascertaining the Curriculum Relevance of the Graduate School through Tracer Study in a Philippine Private Higher Education Institution." percentage of unemployment rate, yet it still not able to assure that all of their graduates got job. In 2020, the open unemployment rate was 7.07 $\%$, increased by $1,84 \%$ from the 2019 survey. From the mentioned percentage, $7,35 \%$ of it was the university graduates. The unemployment rate of the university graduates has also increased during three years period, from 5,88 \% in 2018, slightly declined in 2019 into 5,64\% and increased in 2020 into 7,35\% The percentage of this unemployment rate from the university graduate create paradox among the hope of the societies around the quality and skills attained by the higher degree human resources. While curriculum review is an internal business of a Study Program, greater emphasize on the need to consult and collaborate with the stakeholders due to employability rate of the graduate. ${ }^{8}$ To ascertain the curriculum relevance of the study programs with the market demand, education institutions conduct tracer studies to their graduates and stake holders ${ }^{9} 10{ }^{11}$. The question that raised by Sims 25 might be relevant in this context. Various contributing aspects of the unemployment rate could be related to the curriculum or the missing link between curriculum with stakeholder's needs. ${ }^{12}$

\footnotetext{
BPS, "Berita Resmi Statistik Keadaan Ketenagakerjaan Indonesia Agustus 2020,” 2020. https://www.bps.go.id/pressrelease/2020/11/05/1673 Lagustus-2020--tingkat-pengangguran-terbuka--tpt-sebesar-7-07-persen.html. Accessed at 15 July 2021

8 Christine Brown Wilson and Christine Slade, "From Consultation and Collaboration to Consensus: Introducing an Alternative Model of Curriculum Development," International Journal for Academic Development 25, no. 2 (2020): 189-194.

${ }_{9}$ Bueno, "Ascertaining the Curriculum Relevance of the Graduate School through Tracer Study in a Philippine Private Higher Education Institution."

10 Ernie C Cerado et al., "Enhancing higher education programs through a graduate survey" (2020).

${ }^{11}$ Claire Millington, "The Use of Tracer Studies for Enhancing Relevance and Marketability in Online and Distance Education" (2008).

12 Hanna Hellin Lindsten, Petra Johanna Auvinen, and Tero Sakari Juuti, "Internal and External Stakeholders'impact on Product Development Curriculum Design," in DS 95: Proceedings of the 21st
} 
The involvement of stakeholder within curriculum design is essential because curriculum development and evaluation inform shared necessity both for the graduates and the institutions. For the graduates, the product of curriculum and pedagogy provide them with skills and competence as a resource to the job market. Whereas, for the institutions, developing curriculum is a way to respond the societal changes, in which an essential factor to participate in the global competitions ${ }^{13}$. Higher education institutions could not ignore the ever-changing realities by building effective and responsive academic environment ${ }^{14}$ including the inclusion of technologies support and collaborations of stakeholders in the classrooms. ${ }^{15}$ In general, this is in part because educational system needs to transform its image as the product of industrial revolution and the politics of post-colonialism into a motor for contemporary societies which based on knowledge $e^{16}$.

However, the research about curriculum development, market, and stake holder demands have commonly been done separately. Abundant research on curriculum development have addressed the theories, ideals, stages, and the practices of curriculum

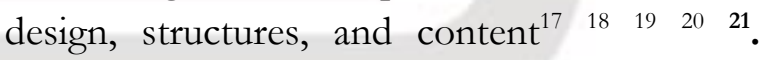
Whereas, the relevancies of educational curriculum with market needs were approached through tracer studies which explore the correlation between market and educational programs 22232425272829 , identify the changing career pattern of the university graduate ${ }^{30}$ or identifying alumni's satisfaction towards the
International Conference on Engineering and Product Design Education (E\&PDE 2019), University of Strathclyde, Glasgow. 12th-13th September 2019, 2019.

${ }^{13}$ Norman Jackson et al., Developing Creativity in Higher Education: An Imaginative Curriculum (Routledge, 2006).

14 Judith Ann Sunderman, Curriculum R\&D: Incubating Change in Higher Education (University of Illinois at Urbana-Champaign, 2011).

${ }^{15}$ Muhammad Ashfaq and Abdul Basit Rana, "A Study of Inclusive Stakeholder's Perceptions for Successful Inclusion at Higher Education in Pakistan," Journal of Research in Social Sciences 3, no. 1 (2015): 80.

${ }^{16}$ Charl C Wolhuter and Alexander W Wiseman, "The Incalculable Promise of the African Continent: Higher Education Rising to the Occasion?," in The Development of Higher Education in Africa: Prospects and Challenges (Emerald Group Publishing Limited, 2013).

17 Brenda Duggan and Brenda Dermody, "14. Design Education For the World of Work: A Case Study of a Problem-Based Learning (PBL) Approach to Design Education At Dublin Institute of Technology (Dit)" (n.d.).

18 Echevarria, "The Contribution of Higher Education to Economic Development in a Globalized Environment."

19 Lubis C, “Need Assessment Dalam Pengembangan Kurikulum Untuk Peningkatan Mutu Pembelajaran Mata Kuliah Kb-Kesehatan Reproduksi Pada Akademi Kebidanan Di Jawa Tengah Dan Jawa Timur" (Universitas Gajah Mada, 2004).

20 Y. Sudarman, "Evaluasi Pelaksanaan Kurikulum Berbasis Kompetensi Di Poltekkes Kementerian Kesehatan Jurusan Keperawatan Prodi Keperawatan Palu"' (Universitas Gajah Mada, 2011).
${ }^{21}$ Sunderman, Curriculum R\&D: Incubating Change in Higher Education.

${ }^{22}$ Rizaldi Akbar and Mukhtar Mukhtar, "Evaluasi E-Tracer Study Menggunakan HOT (HumanOrganization-Technology) Fit Model," Jurnal JTIK (Jurnal Teknologi Informasi dan Komunikasi) 3, no. 2 (2019): 46-51.

23 Muk-Ngiik Wong Annie and Jamil Hamali, "Higher Education and Employment in Malaysia," International Journal of Business and Society 7, no. 1 (2006): 66-76.

24 Bueno, “Ascertaining the Curriculum Relevance of the Graduate School through Tracer Study in a Philippine Private Higher Education Institution."

25 Michael Cosser, "The Skills Cline: Higher Education and the Supply-Demand Complex in South Africa," Higher Education 59, no. 1 (2010): 43.

26 Ryan Jeffrey P Curbano and Ricky V Bustamante, "Graduate Tracer Study for Industrial Engineering Program from Batch 2013 to 2015," in Redesigning Learning for Greater Social Impact (Springer, 2018), 301-311.

27 John S Flomo Jr, Aligning Higher Education to Workforce Needs in Liberia: A Tracer Study of University Graduates in Liberia (University of Minnesota, 2013).

28 Chimango Nyasulu, George Chipeta, and Winner Chawinga, "A Tracer Study of ICT Graduate Students at Mzuzu University, Malawi," Mousaion 36, no. 3 (2018): 1-19.

29 Ulrich Teichler, "Higher Education and the World of Work," Conceptual frameworks (2009).

30 Edna Green Brabham and Susan Kidd Villaume, "Building Walls of Words," The Reading Teacher 54, no. 7 (2001): 700 . 
study program ${ }^{31}$. Stake holders' views have commonly addressed in the research involving nursing studies ${ }^{32}$ and health care related programs. ${ }^{33} 343536$ However, the gap remains open particularly on how tracer study and the practice of accommodating stake holders' voices in curriculum development. This paper seeks to explore how the voices of stake holder is accommodated within the dynamic of curriculum development practices, how to negotiate between staying focus on the core competence of the study program which is to achieve ideal knowledge mastery and to respond to the necessary changes to keep up dated with market demands and educational quality. ${ }^{37}$ This article, in particular tries to add on the study of Alexander and Hjortso ${ }^{38}$ within a narrow scope in the context of Indonesian higher education contexts. While the previous research concerned with broader stakeholders of international agencies, this research points on stake holders within the country by considering that curriculum in higher education institutions is increasingly under pressure to contribute to economic development ${ }^{39}$.

31 Yulistini Yulistini et al., "Tracer study fk unand 2008: persepsi alumni terhadap pelaksanaan pendidikan kedokteran di fakultas kedokteran universitas andalas," Majalah Kedokteran Andalas 34, no. 2 (2015): 167-183.

32 Emily Belita, Nancy Carter, and Denise Bryant-Lukosius, "Stakeholder Engagement in Nursing Curriculum Development and Renewal Initiatives: A Review of the Literature," Quality Advancement in Nursing Education-Avancées en formation infirmière 6, no. 1 (2020): 2.

33 Michael Connolly et al., "Stakeholder Perceptions of Curriculum Design, Development and Delivery for Continuing e-Learning for Nurses," British Journal of Nursing 29, no. 17 (2020): 1016-1022.

34 Kelly O'Brien et al., "Rehabilitation in the Context of HIV: An Interprofessional Multi-Stakeholder Process for Curriculum Development," Journal of allied bealth 39, no. 3 (2010): 131-137.

35 Ashley Singh and Melanie Haynes, "The Challenges of COVID-19 in Nursing Education: The Time for Faculty Leadership Training Is Now," Nurse education in practice 47 (2020): 102831.

36 Marian C Turkel, "Leading from the Heart: Caring, Love, Peace, and Values Guiding Leadership," Nursing Science Quarterly 27, no. 2 (2014): 172-177.

${ }^{37}$ Amirul Islam, "Improving Educational Quality through Curriculum Development: An Empirical
Moreover, listening to the voices of stakeholders, including students, contribute to the success of the study programs and the curriculum itself. ${ }^{40} 414$

In doing so, this research tries to address two questions: (1). How do the Study Programs accommodate their stake holders' voices in the curriculum development process? And (2). What are the challenges of accommodating stake holder's voices in curriculum development practices?

\section{Method}

This paper is based on the authors' field research at one master and three doctoral programs at the oldest and well-known university in Indonesia which is based in Yogyakarta. Further, I use the term study program A, B, C, and D, to keep their confidentiality. This university is among the best public university in Indonesia and become the top choice of students that seek to continue their higher degree education. The research was qualitative in its approach to gain deeper understanding the complexity of the subject

Investigation Using Stakeholder Feedback Data," Journal of Education 199, no. 2 (2019): 69-82.

${ }^{38}$ Ian Keith Alexander and Carsten Nico Hjortsø, "Sources of Complexity in Participatory Curriculum Development: An Activity System and Stakeholder Analysis Approach to the Analyses of Tensions and Contradictions," Higher Education 77, no. 2 (2019): 301322.

${ }^{39}$ Fiona O’Riordan, “Transformational Pedagogy through Curriculum Development Discourse," International Journal of Innovation and Learning 23, no. 2 (2018): 244-260.

40 Rebecca Cairns and Michiko Weinmann, "Towards Asia 'Curriculum-as-Lived': Amplifying Student Voice in the Asia Literacy Curricular Landscape," Asia Pacific Journal of Education (2021): 1-15.

$$
41 \text { Bertrand Guillotin, "Strategic }
$$

Internationalization through Curriculum Innovations and Stakeholder Engagement," Journal of International Education in Business (2018).

42 Rachel Delta Higdon, "Employability: The Missing Voice: How Student and Graduate Views Could Be Used to Develop Future Higher Education Policy and Inform Curricula," Power and Education 8, no. 2 (2016): 176-195. 
under study ${ }^{43}$. The sample was considered using purposive sampling technique in which the sample was chosen judgementally because the researcher has already known the population, while considering the aims of the research ${ }^{44}$. The study programs chosen to represent social and humanities (two study programs) and science-social (two study programs).

The data was gathered through interviews and documentations. The interviews were conducted with the head, secretary, and the administrator of the study programs. With the total participants of 12 people. Those participants were determined by considering their direct involvement in the curriculum development processes. They involved actively since its' planning, envisioning, development, implementation, and evaluation. They also administratively have dealt with the whole process of running the study program. The data also taken from the documents and reports about tracer study and curriculum evaluation of the study programs being studied. The main data were collected between SeptemberOctober 2013 and January 2014 during the first author's master program. Yet it is still relevant with the discussion of current trend of research in the accommodation of stake holders' voices and curriculum development as has been discussed by Alexander and Hjortso ${ }^{45}$.

Findings and Discussion

\section{The Ideals about Curriculum Development}

Developing curriculum is a continualcircular process that require the development of a plan for learning ${ }^{46}$. The process of

43 L Cohen, L Manion, and $\mathrm{K}$ Morrison, "Research Methods in Education.(Sixth Eds)" (London, New York: Taylor \& Francis, 2007).

44 P Dr Sugiyono, "Metode Penelitian Pendidikan: Pendekatan Kuantitatif, Kualitatif, R\&D (Cetakan Ke)," Bandung: CV Alfabeta (2017).

45 Alexander and Hjortsø, "Sources of Complexity in Participatory Curriculum Development: An Activity System and Stakeholder Analysis Approach to the Analyses of Tensions and Contradictions." curriculum development can be implemented through the process called ADDIE (Analyse, Development, Implementation and Evaluation) ${ }^{47}$. Curriculum development bears an understanding that curriculum develops following continuous processes. It is started through a process of curriculum visioning, in which the idea to evaluate a curriculum might come from lecturers to improve students' learning process.

Curriculum visioning comprises of three elements. Firstly, curriculum assessment to gather the data regarding the need to evaluate the curriculum by involving stake holders such as alumni, alumni employers, new students, and graduates. The data is then analysed using SWOT (Strength, Weaknesses, Opportunity, and Threat) analysis. Secondly, program objectives re development to determine the objectives of the study program by articulating the competence and attribute of its graduate. The competences should include the aspects of cognition, affection and psychomotor. Thirdly, program focus which comprises of basic content identification. This is to pinpoint the expected educational experiences. Educational experiences are identified through pedagogy, learning activities, educational services, tutorial, laboratories provided, academic vibes, conferences, and seminars ${ }^{48}$.

The second stage of curriculum development includes curriculum mapping and re/developing program structure. Within this stage the changing of curriculum structures is possible, for example whether a certain subject might become a requirement to take the other

46 Wim Kouwenhoven, "Competence-Based Curriculum Development in Higher Education: A Globalised Concept?," Technology education and development 8, no. 2 (2009): 1-22.

47 Peter Wolf, "A Model for Facilitating Curriculum Development in Higher Education: A Faculty-driven, Data-informed, and Educational Developer-Supported Approach," New Directions for Teaching and Learning 2007, no. 112 (2007): 15-20. 48 Ibid. 
subjects, the sequence of subjects, whether optional subjects need to be added and so forth. The third stage is subject arrangement, coordination, and development by setting up the program, learning objectives, setting up the basis and subjects that will build learning experiences $^{49}$.

On the other hand, to enhance educational experiences, curriculum developers need to consider knowledge on 'a continuum of theory in a non-contextual manner to knowledge that is context related ${ }^{50}$. The non-context theory is related to the generic type and specific discipline of knowledge. Whereas the contextual knowledge pertains to practical side that could be decontextualized through 'pedagogization' and recontextualization in Shay's words. Through the integration of such thinking, curriculum can be developed to support transformative learning experiences for students ${ }^{51}$.

In many cases, the process of curriculum development was often approached using traditional way in which the experts lead and embedded within the university system. However, to accommodate stakeholders' views, participatory paradigm in curriculum design and evaluation is essential. The participatory curriculum development might bring together expertise from many different contexts of the community such as educators, private enterprises, professional associations, alumni, students, and subject experts ${ }^{52}$. Those different stake holders are assumed to have expertise on their particular areas. Inviting stake holders to contribute to make planning

49 Ibid.

50 Suellen Shay, "Conceptualizing Curriculum Differentiation in Higher Education: A Sociology of Knowledge Point of View," British Journal of Sociology of Education 34, no. 4 (2013): p. 563-582.

${ }^{51}$ Ibid.

52 Peter Taylor, "Improving Forestry Education through Participatory Curriculum Development: A Case Study from Vietnam," The Journal of agricultural education and extension 7, no. 2 (2000): p. 93-104. towards educational process will potentially trigger their essential contribution to the creation of more relevant and effective learning ${ }^{53}$. Thus, gathering and accommodating the stakeholders' inputs are pivotal in curriculum evaluation and development.

\section{Garnering Stakeholders' Voices Through Tracer Study: A Strategy}

Among the ways to gather stake holders' voices, regarding the skills and competence of the programs graduate, could be done through the conduct of tracer study. Tracer study is defined as "a kind of systematic analysis of the university, the implementation skills for which can be acquired by university staff members of different professional provenance and functions" ${ }^{\prime 24}$. There are at least three approaches of tracer study, they are: alumni outcome, engagement and competencies and alumni giving approach ${ }^{55}$. In terms of curriculum development, the engagement and competencies approach are the most suitable approach since it seeks to identify the competence of the alumni of the programs, evaluate the process of teaching and learning, as well as the activities outside the formal learning with the alumni capabilities.

In the context of this study, not all those four study programs have conducted a systematic tracer study. The Study Program A, for example have traced it's alumni with the total of 157 people. The program was successful of gathering the data about alumni's profile. Since this study program is a master program leading in the field of religious studies

53 Ibid.

54 Harald Schomburg, "Handbook for Tracer Studies," Centre for Research on Higher Education and Work, University of Kassel, Moenchebergstrasse 17 (2003): 34109.

55 Bhina Patria, "Change Management in the Higher Education Context: A Case of Student-Centred Learning Implementation," International Journal of Education 4, no. 4 (2012): p.176. 
and social sciences, most of its' alumni work in academic fields such as becoming lecturers and researchers, redactor of magazines, educators, NGO activists and many of them were continuing their study into doctoral programs both in the home country and outside. According to the secretary of study program A, besides tracer study, alumni's voices were gathered through various ways such as in the alumni homecoming event or seminars. Moreover, this study program is among the best of having active communication with its alumni through their mailing lists.

Similar to Study Program A, Study Program C which a doctoral program concerns on art and performance studies also owned a very good alumni profiles database. Due to most of its' students were graduated or lecturer at the institutes concerns with arts sciences around Indonesia, its alumni mostly work as lecturers and educators in field of arts and many of them were currently appointed as top leaders in their institutions, as declared by the Secretary of the Study Program C.

On the other hand, The Study Program B, with its big number of alumni, more than 600 people, did not have a systematic database of its alumni. This doctoral program that concerns on studying all related things pertaining to environment and human conducts has a very limited number of staff to manage the huge programs. Resources limitation was a common problem around academic education, not only in Indonesia but also in other country such as Sub Sahara Africa.3

To reach out as much as possible respondents, all the Study Programs used various media to conduct tracer study, such as social media like Face book, websites, email and sending the survey questionnaire manually. Those Study Programs categorized the possible follow up of tracer study response into three categories. First, the data regarding skill assessments in the workplace could be used to evaluate the Subjects whether it needs to add more subjects, put subjects into optional or required subjects and so forth. It also helps the Study Programs to enhance learning experiences for example through internship programs. Secondly, alumni biography and job experiences could be used to develop alumni databases. Thirdly, the nature and content of subjects is used to identify the overlapping contains of certain subjects and consider whether to omit or merge certain subjects (interview with Head of Study Programs D and A).

In terms of labour market signal assessment, the stake holders (employers) of the Study Programs were asked to evaluate 8 aspects of alumni's skills and competences including: self-improvement, Information and Technology (IT) related skills, communication skills, foreign language proficiencies, collaborative skills and team work, leadership, broadmindedness, knowledge competences, and integrity. The users were asked to evaluate those skills and competencies using the standards of Very good as the highest value, followed by good, fair and poor. The following paragraphs highlight the summary report of tracer study, taken from the documents of tracer study report of the four Study Programs.

\section{Study Program A}

In 2011/2012, the Study Program A, garnered 16 responses from the alumni users regarding its' alumni competence. The result showed that integrity, knowledge competencies and self-improvement willingness of the Study Program A's alumni are among that assessed very good by the stakeholders. Whereas, the other skills were viewed as good including IT related skills, teamwork and leadership. None of them gave fair and poor evaluation to the alumni. 


\section{Study Program B}

The Study Program B got responses from 20 users assessing that integrity, broadmindedness and knowledge competences of its' alumni are very good. On the other hand, the other skills such as leadership, team work and IT related skills were valued as good. No alumni of the Study Program B were perceived of demonstrated fair and poor skills.

\section{Study Program C}

Study Program C gathered 21 users' responses. Among 8 skills and competences mentioned above, the alumni of this Study Program were assessed good for all 7 skills, and only 1 very good on alumni’s integrity.

\section{Study Program D}

The responses of 10 users of the Study Program D informed that the very good evaluation was given to alumni's IT related skills, knowledge competences, broadmindedness and self-improvement. Whereas, communication, foreign language mastery and integrity was valued good.

All the skills and competences of the alumni were between very good and good. It can be concluded that, the alumni users are generally satisfied with the ability, skills, knowledge and competences of the graduates from the Study program A, B, C and D.

\section{The Challenges of Accommodating Stakeholder's Voices in the Practice of Curriculum Development}

It is undeniably true that involving the participation of stake holders in curriculum development is pivotal, however, integrating their voices within a participative curriculum development practices remains complex and challenging56. The study programs were challenged by the extent to which

56 Alexander and Hjortsø, "Sources of Complexity in Participatory Curriculum Development: accommodation to the stakeholder voices should be made. Particularly, when they enquire the development of practical skills essential for work, while the study programs must focus on the philosophical vision to develop theories and purely scientific discourses. In addition, the availability of lecturers as human resources in the implementation of the curriculum was also a challenge in curriculum development. Practically, this situation was also experienced by the head of the study programs under studied. Thus, they implement different strategies of accommodating stakeholder voices within their study programs' curriculum.

Study Program A evaluate its' curriculum every three years and has conducted the routine since 2002. The curriculum development practices covered many different areas such as the change of course title, changes in scientific cluster (major), addition of new courses as well as merging two courses into one. The Secretary of the Study Program A states:

"Curriculum changes in this study program is scheduled every three years. For example, the evaluation of curriculum for 2014, the workshop was conducted in the end of 2013. It is routine like that...the evaluation was done firstly by adjusting to the context in the field of the study. There is some development, usually we keep the update through discussed topics around the world. We shift our focus following that. The other consideration was usually reflected when the lecturers conduct teaching and learning activities and class interactions. 
We have lecturers' meeting, and almost every day we meet each other. During the meeting we usually share the challenges and difficulty they face, if there some overlapping subjects, together we seek the solution."

Regarding alumni's voices, during the alumni homecomings, the Head of the Study Programs discuss and invited the aspiration and feedback from the alumni about their learning experiences. For example, one of the alumni from Study Program A suggest a subject to be added to the study program that might enrich their knowledge competence in their work institutions, in his case is a subject about religious education because many of the alumni work as teachers. As a response, the study program A accommodated it by offering an elective course on religious education (Interview with the Head of Study Program A).

On the other hand, for the Head of Study Program B, concerned with the 'scientific core' of the study programs. Some study programs develop more applicative sciences, while the other, concerned more on pure sciences. Maintaining this scientific core is challenging for a study program particularly in regards to changes in the society. Responding this issue, the Head of the Study program B asserted that the curriculum development was focused more on the content of the courses taught by the lecturers, rather than the name of the course or the curriculum structures. He agreed that ideally the curriculum is evaluated every 5 years. However, he argued that it should be based on 'scientific core' of the study program whether it is purely scientific or applicative. He stated:

"The scientific core of Study program B is basic sciences, in essence the core content of the course remains on the basis of the science, yet how the courses were delivered was the most important thing. For example, the course about ecology...the correlation of human and ecology, environment is always developing and evolving. The advancement of technologies cannot be separated from human interaction and their environment. Another example is the pollution in the last time is not the same".

Another challenge was the availability of human resources and lecturers in delivering the curriculum in the form of courses. Curriculum development was done on the basis of adapting to the changes of current situation, but it also rely heavily on the existing human resources of the programs including lecturers as the backbone of a study program ${ }^{57}$. From 1991 to 2005, the Study Program C, conducted curriculum review by adding or subtracting the units of the course, or developing the elective scientific major, yet according to the alumni and lecturer of this study program, the evaluation was not very significant due to the lack number of lecturers owned by this program. Conversely, in 2012, by the changing of the Study Program head, Study Program C conducted a major evaluation towards the curriculum. Not only by changing the courses, the lecturers who were appointed to teach such courses, but also there was a big change in the content of the curriculum. The Secretary to the Study Program C mentioned:

"The limitation of the previous curriculum was the nonexistence of elective course for students. This was pointed out during internal quality audit. So, the Study Program tried to

57 Ibid. 
merge the courses about ethnomusicology from I and II, into only one subject...to put the new elective subject in the curriculum, such as art and religion, art criticism, art and tourism...this curriculum evaluation was aimed at giving the specialty of this Study Program from the similar study program in other universities"

The conduct of the above curriculum development was by bringing together the lecturers of the study program, the experts in the field of study from outside of the university, alumni, students, and the administrative staff.

The Study Program D, on the other hand, focused its curriculum development on the omission of internship program. This deletion was based on the evaluation towards the program implementation so far. In the beginning, internship was designed to facilitate students to implement the theories they learn during their study into the real work life or use it to solve problems in the society. From the internship, students also have opportunity to identify the problems or gaps in the society that need further research for their thesis will be. However, based on students' experiences, internship was not able to be conducted as ideal as it should be. The problem in the fields was a lot complex which involve external institutions. So, due to ineffective conduct and poor evaluation from the students, during 2010 curriculum evaluation agenda, the subject on internship was omitted in the Study Program D (interview with the administrative staff of Study Program D).

Accommodating stake holders' feedback in the curriculum evaluation is essential to develop the Study Program. Stake holders' voices that were gathered from tracer study,

58 Khalid M Al-Jubran, “A Stakeholders Approach for Curriculum Development of Master's survey or formal meeting would help to identify the curriculum components, very helpful to establish the needs and expectations of the stakeholders concerning the graduate's competencies $^{58}$. This method, for example can be conducted by surveying experts and supervisors including professors in the related field of study from various universities, consultants, and supervisors at the related institutions to assess their expectation in terms of cognitive and psychomotor competences of master or doctor graduated in such field study. However, the practice of accommodating stake holder's inputs within curriculum development process is not simple. Challenges remain existed since the process of garnering their voices, in the process of curriculum formation by considering scientific core of a study programs, as well as the availability of human resources in the implementation stage.

\section{Conclusion}

Curriculum reform is a core process in higher education system because from the curriculum, graduates' competences were developed. As a continuous circle, curriculum development is not an end product of an educational planning, but it needs to be overlooked and evaluated at least every 5 years according to Indonesian education system. in doing so, a participatory approach is an alternative way to involve the stake holders' views and expectations to provide overview of the current competences needed in certain job market as well as experts' views on the development of scientific trends in the field. However, the practice of curriculum development was not absent from challenges. This is because the post graduate programs do not only concern about market demand and how to meet the needs of the industry, but also on how to develop theories and knowledge. 
While accommodating the perspective of stake holder is in part challenging, the study programs under study showed their effort to invite experts, alumni users from outside of the university, listened to their feedback and evaluations and accommodate them within the process of curriculum review and curriculum design.

\section{References}

Book

C, Lubis. "Need Assessment Dalam Pengembangan Kurikulum Untuk Peningkatan Mutu Pembelajaran Mata Kuliah Kb-Kesehatan Reproduksi Pada Akademi Kebidanan Di Jawa Tengah Dan Jawa Timur." Universitas Gajah Mada, 2004.

Cerado, Ernie C, Mary Jean S Falsario, Jocelyn

C Estrellan, and Allan Rey M Paculanan.

"Enhancing Higher Education Programs Through A Graduate Survey" (2020).

Cohen, L, L Manion, and $\mathrm{K}$ Morrison. "Research Methods in Education.(Sixth Eds)." London, New York: Taylor \& Francis, 2007.

Duggan, Brenda, and Brenda Dermody. "14. design Education for the World of Work: a Case Study of a Problem-Based Learning (pbl) Approach to Design Education at Dublin Institute of Technology (DIT)" (n.d.).

Echevarria, Domingo G. "The Contribution of Higher Education to Economic* Development in a Globalized Environment." Florida International University, 2009.

Flomo Jr, John S. Aligning Higher Education to Workforce Needs in Liberia: A Tracer Study of University Graduates in Liberia. University of Minnesota, 2013.

Jackson, Norman, Martin Oliver, Malcolm Shaw, and James Wisdom. Developing Creativity in Higher Education: An Imaginative Curriculum. Routledge, 2006.

Millington, Claire. "The Use of Tracer Studies for Enhancing Relevance and Marketability in Online and Distance Education" (2008).
Prihatiningsih, T. S. "Trans-, Multi- Dan InterDisciplinary Higher Education',," Universitas Gadjah Mada, 2013.

Schomburg, Harald. "Handbook for Tracer Studies." Centre for Research on Higher Education and Work, University of Kassel, Moenchebergstrasse 17 (2003): 34109.

Sims, Margaret. Bullshit Towers: Neoliberalism and Managerialism in Universities in Australia. Peter Lang, 2020.

Sugiyono, P Dr. "Metode Penelitian Pendidikan: Pendekatan Kuantitatif, Kualitatif, R\&D (Cetakan Ke).” Bandung: CV Alfabeta (2017).

Sunderman, Judith Ann. Curriculum R\&D: Incubating Change in Higher Education. University of Illinois at UrbanaChampaign, 2011.

Teichler, Ulrich. "Higher Education and the World of Work." Conceptual frameworks (2009).

Wolhuter, Charl C, and Alexander W Wiseman. "The Incalculable Promise of the African Continent: Higher Education Rising to the Occasion?" In The Development of Higher Education in Africa: Prospects and Challenges. Emerald Group Publishing Limited, 2013.

Y. Sudarman. "Evaluasi Pelaksanaan Kurikulum Berbasis Kompetensi Di Poltekkes Kementerian Kesehatan Jurusan Keperawatan Prodi Keperawatan Palu."' Universitas Gajah Mada, 2011.

\section{Journal}

Akbar, Rizaldi, and Mukhtar Mukhtar. "Evaluasi E-Tracer Study Menggunakan HOT (Human-OrganizationTechnology) Fit Model." Jurnal JTIK (Jurnal Teknologi Informasi dan Komunikasi) 3, no. 2 (2019): 46-51.

Al-Jubran, Khalid M. "A Stakeholders Approach for Curriculum Development of Master's Degree in Molecular Diagnostics." Advances in Medical Education and Practice 11 (2020): 683.

Alexander, Ian Keith, and Carsten Nico Hjortsø. "Sources of Complexity in Participatory Curriculum Development: An Activity System and Stakeholder Analysis Approach to the Analyses of Tensions and Contradictions." Higher 
Education 77, no. 2 (2019): 301-322.

Annie, Muk-Ngiik Wong, and Jamil Hamali. "Higher Education and Employment in Malaysia." International Journal of Business and Society 7, no. 1 (2006): 66-76.

Brabham, Edna Green, and Susan Kidd Villaume. "Building Walls of Words." The Reading Teacher 54, no. 7 (2001): 700.

Bueno, David C. "Ascertaining the Curriculum Relevance of the Graduate School through Tracer Study in a Philippine Private Higher Education Institution." JPAIR Multidisciplinary Research Journal 28, no. 1 (2017): 1.

Cosser, Michael. "The Skills Cline: Higher Education and the Supply-Demand Complex in South Africa." Higher Education 59, no. 1 (2010): 43.

Curbano, Ryan Jeffrey P, and Ricky V Bustamante. "Graduate Tracer Study for Industrial Engineering Program from Batch 2013 to 2015." In Redesigning Learning for Greater Social Impact, 301-311. Springer, 2018.

Kouwenhoven, Wim. "Competence-Based Curriculum Development in Higher Education: A Globalised Concept?" Technology education and development 8, no. 2 (2009): 1-22.

Nyasulu, Chimango, George Chipeta, and Winner Chawinga. "A Tracer Study of ICT Graduate Students at Mzuzu University, Malawi." Mousaion 36, no. 3 (2018): 1-19.

O'Riordan, Fiona. "Transformational Pedagogy through Curriculum Development Discourse." International Journal of Innovation and Learning 23, no. 2 (2018): 244-260.

Patria, Bhina. "Change Management in the Higher Education Context: A Case of Student-Centred Learning Implementation." International Journal of Education 4, no. 4 (2012): 176.

Shay, Suellen. "Conceptualizing Curriculum Differentiation in Higher Education: A Sociology of Knowledge Point of View." British Journal of Sociology of Education 34, no. 4 (2013): 563-582.

Taylor, Peter. "Improving Forestry Education through Participatory Curriculum
Development: A Case Study from Vietnam." The Journal of agricultural education and extension 7, no. 2 (2000): 93-104.

Wolf, Peter. "A Model for Facilitating Curriculum Development in Higher Education: A Faculty-driven, Datainformed, and Educational DeveloperSupported Approach." New Directions for Teaching and Learning 2007, no. 112 (2007): 15-20.

Yulistini, Yulistini, Aisyah Elliyanti, Nora Harminarti, Taufik Ashal, and Ilmiati Ilmiati. "Tracer Study FK Unand 2008: Persepsi Alumni Terhadap Pelaksanaan Pendidikan Kedokteran Di Fakultas Kedokteran Universitas Andalas." Majalah Kedokteran Andalas 34, no. 2 (2015): $167-$ 183.

\section{Online References}

Akbar, Rizaldi, and Mukhtar Mukhtar. "Evaluasi E-Tracer Study Menggunakan HOT (Human-OrganizationTechnology) Fit Model." Jumal JTIK (Jurnal Teknologi Informasi dan Komunikasi) 3, no. 2 (2019): 46-51.

Al-Jubran, Khalid M. "A Stakeholders Approach for Curriculum Development of Master's Degree in Molecular Diagnostics." Advances in Medical Education and Practice 11 (2020): 683.

Alexander, Ian Keith, and Carsten Nico Hjortsø. "Sources of Complexity in Participatory Curriculum Development: An Activity System and Stakeholder Analysis Approach to the Analyses of Tensions and Contradictions." Higher Education 77, no. 2 (2019): 301-322.

Annie, Muk-Ngiik Wong, and Jamil Hamali. "Higher Education and Employment in Malaysia." International Journal of Business and Society 7, no. 1 (2006): 66-76.

Ashfaq, Muhammad, and Abdul Basit Rana. "A Study of Inclusive Stakeholder's Perceptions for Successful Inclusion at Higher Education in Pakistan." Journal of Research in Social Sciences 3, no. 1 (2015): 80.

Belita, Emily, Nancy Carter, and Denise Bryant-Lukosius. "Stakeholder Engagement in Nursing Curriculum Development and Renewal Initiatives: A 
Review of the Literature." Quality Advancement in Nursing Education-Avancées en formation infirmière 6, no. 1 (2020): 2.

BPS. "Berita Resmi Statistik Keadaan Ketenagakerjaan Indonesia Agustus 2020," 2020.

Brabham, Edna Green, and Susan Kidd Villaume. "Building Walls of Words." The Reading Teacher 54, no. 7 (2001): 700.

Brown Wilson, Christine, and Christine Slade. "From Consultation and Collaboration to Consensus: Introducing an Alternative Model of Curriculum Development." International Journal for Academic Development 25, no. 2 (2020): 189-194.

Bueno, David C. "Ascertaining the Curriculum Relevance of the Graduate School through Tracer Study in a Philippine Private Higher Education Institution." JPAIR Multidisciplinary Research Journal 28, no. 1 (2017): 1.

Cairns, Rebecca, and Michiko Weinmann. 'Towards Asia 'Curriculum-as-Lived': Amplifying Student Voice in the Asia Literacy Curricular Landscape." Asia Pacific Journal of Education (2021): 1-15.

Connolly, Michael, Freda Browne, Geraldine Regan, and Mary Ryder. "Stakeholder Perceptions of Curriculum Design, Development and Delivery for Continuing e-Learning for Nurses." British Journal of Nursing 29, no. 17 (2020): 10161022.

Cosser, Michael. "The Skills Cline: Higher Education and the Supply-Demand Complex in South Africa." Higher Education 59, no. 1 (2010): 43.

Curbano, Ryan Jeffrey P, and Ricky V Bustamante. "Graduate Tracer Study for Industrial Engineering Program from Batch 2013 to 2015." In Redesigning Learning for Greater Social Impact, 301-311. Springer, 2018.

Diver, A. Employability via Higher Education: Sustainability as Scholarship Edited by Alice Diver. 1st ed. 20. Cham: Springer International Publishing: Imprint: Springer., 2019. https://doi.org/10.1007/978-3-03026342-3 .

Guillotin,

Bertrand.
Internationalization through Curriculum Innovations and Stakeholder Engagement." Journal of International Education in Business (2018).

Higdon, Rachel Delta. "Employability: The Missing Voice: How Student and Graduate Views Could Be Used to Develop Future Higher Education Policy and Inform Curricula." Power and Education 8, no. 2 (2016): 176-195.

Islam, Amirul. "Improving Educational Quality through Curriculum Development: An Empirical Investigation Using Stakeholder Feedback Data." Journal of Education 199, no. 2 (2019): 69-82.

Kouwenhoven, Wim. "Competence-Based Curriculum Development in Higher Education: A Globalised Concept?" Technology education and development 8, no. 2 (2009): 1-22.

Lindsten, Hanna Hellin, Petra Johanna Auvinen, and Tero Sakari Juuti. "Internal And External Stakeholders'impact On Product Development Curriculum Design." In DS 95: Proceedings of the 21st International Conference on Engineering and Product Design Education (E\&PDE 2019), University of Strathclyde, Glasgow. 12th-13th September 2019, 2019.

Nyasulu, Chimango, George Chipeta, and Winner Chawinga. "A Tracer Study of ICT Graduate Students at Mzuzu University, Malawi." Mousaion 36, no. 3 (2018): 1-19.

O’Brien, Kelly, Gillian Bone, Lynne Sinclair, and Patricia Solomon. "Rehabilitation in the Context of HIV: An Interprofessional Multi-Stakeholder Process for Curriculum Development." Journal of allied bealth 39, no. 3 (2010): 131-137.

O'Riordan, Fiona. "Transformational Pedagogy through Curriculum Development Discourse." International Journal of Innovation and Learning 23, no. 2 (2018): 244-260.

Patria, Bhina. "Change Management in the Higher Education Context: A Case of Student-Centred Learning Implementation." International Journal of Education 4, no. 4 (2012): 176.

Shay, Suellen. "Conceptualizing Curriculum 
Differentiation in Higher Education: A Sociology of Knowledge Point of View." British Journal of Sociology of Education 34, no. 4 (2013): 563-582.

Singh, Ashley, and Melanie Haynes. "The Challenges of COVID-19 in Nursing Education: The Time for Faculty Leadership Training Is Now." Nurse education in practice 47 (2020): 102831.

Taylor, Peter. "Improving Forestry Education through Participatory Curriculum Development: A Case Study from Vietnam." The Journal of agricultural education and extension 7, no. 2 (2000): 93-104.
Turkel, Marian C. "Leading from the Heart: Caring, Love, Peace, and Values Guiding Leadership." Nursing Science Quarterly 27, no. 2 (2014): 172-177.

Wolf, Peter. "A Model for Facilitating Curriculum Development in Higher Education: A Faculty-driven, Datainformed, and Educational DeveloperSupported Approach." New Directions for Teaching and Learning 2007, no. 112 (2007): 15-20.

Yulistini, Yulistini, Aisyah Elliyanti, Nora Harminarti, Taufik Ashal, and Ilmiati Ilmiati. "Tracer Study Fk Unand 2008: Persepsi Alumni Terhadap Pelaksanaan Pendidikan Kedokteran Di Fakultas Kedokteran Universitas Andalas." Majalah Kedokteran Andalas 34, no. 2 (2015): 167183. 